\title{
Blastocyst implantation failure relates to impaired translational machinery gene expression
}

\author{
Vicki Plaks ${ }^{1, *},+$, Eran Gershon ${ }^{1,{ }^{*},{ }^{*}}$, Amit Zeisel ${ }^{2, *}$, Jasmine Jacob-Hirsch ${ }^{4}$, Michal Neeman ${ }^{1}$, \\ Elke Winterhager $^{3}$, Gideon Rechavi ${ }^{4}$, Eytan Domany ${ }^{2}$ and Nava Dekel ${ }^{1}$ \\ Departments of ${ }^{1}$ Biological Regulation and ${ }^{2}$ Physics of Complex Systems, The Weizmann Institute of Science, \\ Rehovot 76100, Israel, ${ }^{3}$ Institute of Anatomy, University Hospital Duisburg-Essen, Essen, Germany and ${ }^{4}$ The Sheba \\ Cancer Research Center, Sheba Medical Center, Tel Hashomer, Israel \\ Correspondence should be addressed to N Dekel; Email: Nava.dekel@weizmann.ac.il
}

*(V Plaks, E Gershon and A Zeisel contributed equally to this work)

${ }^{+} \mathrm{V}$ Plaks is now at Department of Anatomy, University of California, San Francisco, California, USA

${ }^{\ddagger} \mathrm{E}$ Gershon is now at Department of Ruminant Science, The Volcani Center, Bet Dagan, Israel

\begin{abstract}
Oocyte quality is a well-established determinant of embryonic fate. However, the molecular participants and biological markers that affect and may predict adequate embryonic development are largely elusive. Our aim was to identify the components of the oocyte molecular machinery that part take in the production of a healthy embryo. For this purpose, we used an animal model, generated by us previously, the oocytes of which do not express $\mathrm{Cx} 43\left(\mathrm{Cx} 43^{\mathrm{del} / \mathrm{del}}\right)$. In these mice, oogenesis appears normal, fertilisation does occur, early embryonic development is successful but implantation fails. We used magnetic resonance imaging analysis combined with histological examination to characterise the embryonic developmental incompetence. Reciprocal embryo transfer confirmed that the blastocyst evolved from the $\mathrm{Cx}_{4} 3^{\mathrm{del} / \mathrm{del}}$ oocyte is responsible for the implantation disorder. In order to unveil the genes, the impaired expression of which brings about the development of defective embryos, we carried out a genomic screening of both the oocytes and the resulting blastocysts. This microarray analysis revealed a low expression of Egr1, Rpl21 and Eif4a1 in Cx43 ${ }^{\text {del/del }}$ oocytes and downregulation of Rpl15 and Eif4g2 in the resulting blastocysts. We propose that global deficiencies in genes related to the expression of ribosomal proteins and translation initiation factors in apparently normal oocytes bring about accumulation of defects, which significantly compromise their developmental capacity. The blastocysts resulting from such oocytes, which grow within a confined space until implantation, may be unable to generate enough biological mass to allow their expansion. This information could be implicated to diagnosis and treatment of infertility, particularly to IVF.
\end{abstract}

Reproduction (2014) 148 87-98

\section{Introduction}

It is well established that oocyte quality has a major impact on the fate of pregnancy (Krisher 2004). However, the molecular participants that determine the properties of an oocyte remain largely unknown and biological markers that may predict its chances to develop into a healthy embryo are practically unavailable. Moreover, even when oogenesis along with folliculogenesis seem to be completed successfully, there are apparently some, hitherto unidentified, specific processes occurring within the oocyte that are required for acquisition of developmental competence. These processes, collectively defined as cytoplasmic maturation (Eppig 1996, De Sousa et al. 1998), may be essential for the successful development of the embryo before and after activation of the zygotic genome. Developmental incompetence is frequently associated with aneuploidy (Baird et al. 2005).
Additive causes of oocyte developmental incompetence include inappropriate oocyte metabolism (Lane \& Gardner 2000), disturbed ions transport and faulty mitochondrial function (Krisher 2004, Dumollard et al. 2007).

Beyond intraoocyte factors, developmental competence is greatly influenced by the ability of the ovary to supply the oocyte with nutrients facilitating its growth (Eppig 1996). Cell-to-cell communication in the ovarian follicle is established by gap junctions during fetal life (embryonic day 11.5 (Perez-Armendariz et al. 2003)) and persists throughout the later stages of follicular growth (Mitchell \& Burghardt 1986). These channels also facilitate the supply of cAMP (Dekel et al. 1981) as well as cGMP (Norris et al. 2009, Vaccari et al. 2009), maintaining the oocyte in meiotic arrest. A gap junction channel consists of two connexons, each comprising six connexin (CX) proteins (Unger et al. 1999) that are 
docked in the plasma membrane of closely apposed cells (Sosinsky \& Nicholson 2005). Several CXs have been detected in the ovarian follicles of different species, among which the indispensability of connexin 37 (Cx37, encoded by the gene Gja4) and connexin 43 (Cx43, encoded by the gene Gja1) has been demonstrated (Gittens \& Kidder 2005, Gershon et al. 2008a). In a model of $C \times 37$ knockout (KO) mouse, both germ cell development and ovarian folliculogenesis were arrested at an early stage (Simon et al. 1997). In order to circumvent postnatal lethality in mice that lack $C_{x} 43$ (Reaume et al. 1995), ovaries removed from $C \times 43$ KO mice prenatally, were allowed to further develop either in vitro, in organ culture, or in vivo, under the kidney capsule of WT mice. Under both experimental conditions, folliculogenesis in Cx43-deficient ovaries did not proceed beyond the primary follicle stage, and oocyte growth was retarded. Furthermore, oocytes recovered from these grafts failed to resume meiosis and could not be fertilised (Juneja et al. 1999, Ackert et al. 2001).

In an attempt to direct the depletion of Gja1 to the oocyte, we used previously the cre-loxP strategy (Gershon et al. 2008b). In this study, we crossed females that carry a $C x 43$ coding region, flanked by loxP recognition sites, with males expressing the Cre recombinase under the control of $Z p 3$ promoter. Oocytes of the resultant Zp3Cre;Gja1 lox/lox female mice did not express $\mathrm{C} \times 43$ and were referred to as $\mathrm{C} \times 43^{\mathrm{del} / \mathrm{del}}$. Although a decrease in $\mathrm{C} \times 43$ was also observed in the cumulus/granulose cells of some of the follicles as well, the Zp3Cre;Gja ${ }^{\text {lox/lox }}$ mice ovulated mature fertilisable oocytes. However, their mating with WT males resulted in a reduced rate of parturition and a substantial decrease in litter size that was apparently attributed to implantation failure of the blastocysts.

The subfertility of Zp3Cre;Gja1 $1^{\text {lox/lox }}$ females may represent an impaired quality of the $\mathrm{C} \times 43^{\text {del/del }}$ oocytes, suggesting that those processes within the oocytes that are essential for acquisition of developmental competence may require the expression of $C \times 43$. However, the failure of such processes to occur can also be secondary to the reduced expression of $C \times 43$ in the cumulus/granulose cells that result in inadequate cell-to-cell communication. These processes may include mRNA transcription, protein translation and post-translational modifications. Yet, the oocytes that reside in this follicular Cx43-defective environment developed into blastocysts, which are unable to implant effectively. The exact mechanism that underlies this implantation failure was unresolved. Nevertheless, this animal model represents a particular example of oocytes that seem to undergo normal oogenesis according to standard morphological and functional parameters, but are developmentally incompetent. In the present study, we employed the Zp3Cre; Gja $1^{\text {lox/lox }}$ mouse model generated by us previously. We hypothesised that an impaired gene expression might be responsible for the development of the defective embryos. In an attempt to unveil these genes, we carried out a genomic screening of both the oocytes and the resulting blastocysts. We herein provide evidence that oocyte developmental incompetence is associated with global defects in ribosomal proteins, translation initiation factors and other genes associated with cellular biosynthetic and metabolic processes. These genes are apparently dispensable for normal oogenesis, fertilisation and early embryonic development, but may affect the ability of the blastocysts to progress beyond this embryonic stage.

\section{Materials and methods}

\begin{abstract}
Animals
Transgenic, C57BL/6-Tg(Zp3-cre)3Mrt/J male mice expressing the Cre recombinase, under the control of $Z p 3$ promoter (de Vries et al. 2000), were purchased from Jackson Laboratories (Bar Harbor, ME, USA). The Cx43 $3^{\text {lox/lox }}$ mice (Theis et al. 2001) were kindly provided by Klaus Willecke, University of Bonn, Germany. The Zp3Cre;Gja1 ${ }^{\text {lox/lox }}$ females were previously generated in our laboratory (Gershon et al. 2008b). Mice were maintained on a $12 \mathrm{~h}$ light: $12 \mathrm{~h}$ darkness cycle. All animal experiments were approved by the Weizmann Institutional Animal Care and Use Committee.
\end{abstract}

\section{Animal treatment}

Sexually immature 23-day-old female mice received 5 IU of pregnant mare's serum gonadotropin (PMSG Chrono-gest Intervet, Boxmeer, The Netherlands) for stimulation of follicle development. Ovulation was induced by injecting $5 \mathrm{IU}$ of human chorionic gonadotropin (hCG, Chrono-gest Intervet) $48 \mathrm{~h}$ after PMSG administration. The animals were killed by cervical dislocation $24 \mathrm{~h}$ later and the ovulated oocytes arrested at the second metaphase (MII) were collected from the oviductal ampula. To achieve pregnancy, 25-day-old, PMSG/hCG-treated female mice were housed overnight with males and examined the next morning for the presence of a vaginal plug. This day of pregnancy is defined as embryonic day 0.5 (E0.5). Pseudopregnancy was achieved by mating the PMSG/hCG-treated females with vasectomised males of proven sterility.

\section{Genotype analysis}

Genomic DNA from mouse tail was extracted using the Direct PCR Kit (Viagen, Los Angeles, CA, USA) according to the manufacturer protocol. The PCR conditions for genotyping the Cx43-lox transgene in the Zp3Cre;Gja1 lox/lox mice were described previously (Gershon et al. 2008b). The PCR conditions for genotyping the Cre recombinase transgene in Zp3-Cre mice were described previously (Lan et al. 2004).

\section{In vivo contrast-enhanced magnetic resonance imaging studies}

Contrast-enhanced magnetic resonance imaging (MRI) experiments were carried out on a horizontal 4.7 T Bruker Biospec spectrometer (Bruker, Karlsruhe, Germany) as previously 
Table 1 PCR primers list.

\begin{tabular}{lllc}
\hline Gene & Forward primer & Reverse primer & $\boldsymbol{T}_{\mathbf{m}}\left({ }^{\circ} \mathrm{C}\right)$ \\
\hline Connexin43 & CTTCCAGTATCATTTTGGGAAAAG & TGGATTGTTCTTCATCTC & 55 \\
Connexin26 & ACTCCACCAGCATTGGAAAG & GGAAGTGGTGGTCGTAGCAT & 55 \\
Cre-zp3 & ATGCTTCTGTCCGTTTGCC & CGCTCGACCAGTTTAGTTACC & 55 \\
$\beta$-actin & CCCCATTGAACATGGCATTGTTAC & TTGATGTCACGCACGATTTCC & 55 \\
\hline
\end{tabular}

described (Plaks et al. 2006). In brief, at the pregnancy days indicated (E4.5, E5.5 and E9.5), the females were anesthetised by an i.p. injection of $75 \mathrm{mg} / \mathrm{kg}$ ketamine (ketast; Fort Dodge Laboratories, Fort Dodge, IA, USA) combined with $3 \mathrm{mg} / \mathrm{kg}$ xylasine ( $2 \%$ Xylen; VMD, Arendonk, Belgium). A series of variable-flip-angle precontrast $T 1$-weighted $3 \mathrm{D}$ gradient-echo (3D-GE) images were acquired, after which, a bolus of BSAbased macromolecular contrast material, biotin-BSA-Gd-DTPA (biotin3-BSA-Gd-DTPA33; about $82 \mathrm{kDa}$ ), was injected through a tail vein catheter (18 mg/mouse in $0.2 \mathrm{ml} \mathrm{PBS})$.

For dynamic postcontrast imaging, T1-weighted 3D-GE images were acquired from the time of biotin-BSA-Gd-DTPA administration and up to $15 \mathrm{~min}$. At the end of the MRI session, Evans blue (Sigma; $1 \% \mathrm{w} / \mathrm{v}$ in saline, $100 \mu \mathrm{l}$ ) was intravenously injected via the tail vein and allowed to circulate for $10 \mathrm{~min}$ to enable ex vivo detection of implantation sites.

\section{Histology}

Uteri were fixed in Carnoy's solution (BDH Chemicals, Radnor, PA, USA) for $24 \mathrm{~h}$ and paraffin embedded. Cross sections of $5 \mu \mathrm{m}$ were mounted on slides. The sections were either stained by haematoxylin and eosin (H\&E) or processed for immunofluorescence analysis as described later.

Quantification of decidualisation was performed on sections with the widest decidual diameter using the (ImageJ software, http://imagej.nih.gov/ij/). Staining intensity was measured in absolute counts. The average intensity was calculated by the ratio of the signal to the area of the region of interest.

\section{Immunohistochemistry}

Immunohistochemistry was carried out as described previously (Israely et al. 2003, Plaks et al. 2006). Briefly, uterine samples with implantation sites were fixed in Carnoy's solution, sectioned serially at $4 \mu \mathrm{m}$ thickness, and stained by $\mathrm{H} \& \mathrm{E}$, as well as by the proliferation marker Ki67 (Monoclonal Rat Anti-Mouse Ki-67 Antigen, Dako, Glostrup, Denmark, 1:100). For this purpose, the sections were incubated with Ki67 primary antibody followed by anti-rat-HRP-conjugated secondary antibody (Thermo Scientific, Waltham, MA, 1:1000). The endogenous peroxidase was inactivated using 5:1 methanol to $\mathrm{H}_{2} \mathrm{O}_{2}(30 \%)$ solution, and the Ki67 staining was detected using the 3,3'-diaminobenzidine Substrate Kit (Abcam, Cambridge, UK).

\section{Immunofluorescence staining}

Immunofluorescent staining of (Gjb2) $C \times 26$ and $C \times 43$ was carried out on deparaffinised sections washed in PBS. Blocking of non-specific binding was obtained by incubating the sections for 30 min with 3\% FCS in PBS. Antigen retrieval was done by the standard sodium citrate method as well as by incubation in trypsin-EDTA (Sigma, $0.25 \%$ ) for $5 \mathrm{~min}$. The sections were then incubated overnight at $4{ }^{\circ} \mathrm{C}$ with either anti-Cx26 or anti-Cx43 antibodies (anti-Cx26 rabbit polyclonal antibody, 1:50 and mouse monoclonal anti-Cx43 antibody, 1:100, both from Invitrogen). The sections were washed with PBS and immunoreacted with either Alexa 594 or Alexa 488-conjugated secondary antibodies, respectively (Jackson Immunoresearch Laboratories, West Grove, PA, USA), for $1 \mathrm{~h}$ at room temperature. The sections were washed three times with PBS and visualised, using a fluorescence microscope (Nikon, Tokyo, Japan). All images were taken under identical illumination conditions with either a green filter for Alexa 488 or a red filter for Alexa 594.

\section{Sample collection for RNA extraction}

Ovaries were collected from females at 2, 5 and 15 days post-natal as well as from 25-day-old female mice treated with PMSG-hCG for induction of ovulation. Ovulated MII oocytes were collected from the oviductal ampoule of the above-mentioned mice 1 day later. Blastocysts were washed from the uteri of pregnant females on E4.5 and implantation sites were recovered on this same day of pregnancy from mice intravenously injected with Evans blue. All samples were collected from both WT and Zp3Cre;Gja1 ${ }^{\text {lox/lox }}$ mice. Samples were immediately frozen in liquid nitrogen and processed for RNA extraction and PCR analysis.

\section{RT analysis}

Total RNA was extracted from oocytes and blastocysts using Trireagent according to manufacturer protocol (Sigma). RNAs at the implantation sites were extracted using the EZ RNAII Kit,

Table 2 Real-time PCR primers list.

\begin{tabular}{lllc}
\hline Gene & Forward primer & Reverse primer & $\boldsymbol{T}_{\mathbf{m}}\left({ }^{\circ} \mathrm{C}\right)$ \\
\hline Egr1 & CTATGATGATCTGTCACCAGTGTCTA & GACCAAAGCTCCTCCCTCA & 60 \\
Eif4a1 & TCATGTCTGCGAGTCAGGAT & GCTATCCACAATCTCGTTCCA & 60 \\
Rps6 & AAAGAAACACAGCCTTTAAAGTAAAAA & GGACAGAAGTTAATCTTTTAGCAAGT & 59 \\
Rlp21 & ATGGTGTGAATGTGGGTACG & TGGAAGATGATGACAATTCTGTG & 59 \\
Rpl15 & GTGGATCACCAAACCAGTCC & CTGGAGAGTATTGCGCCTTC & 60 \\
Eif4g & AGAGTTGCGAGAGCACCATT & GGTCCCTCCAGGAAGAAGTC & 60 \\
B $2 \mathrm{M} 1$ & CCCGCCTCACATTGAAATCC & GCGTATGTATCAGTCTCAGTGG & 58 \\
\hline
\end{tabular}


according to manufacturer protocol (Biological Industries, Kibbutz Beit Haemek, Israel). RT was carried out by mixing $1 \mu \mathrm{g}$ RNA with $4 \mu \mathrm{l}$ of MMLV-RT $5 \times$ reaction buffer (Promega), $10 \mathrm{mM}$ dNTP, $0.5 \mu \mathrm{g}$ oligo (dT) ${ }_{12-18}$ (Promega), 40 units of RNasin (Promega), 200 units of Moloney murine leukemia virus reverse transcriptase (M-MLV Reverse transcriptase, Promega) and $3 \mu \mathrm{l}$ DDW. This mixture was incubated at $37^{\circ} \mathrm{C}$ for $2 \mathrm{~h}$.
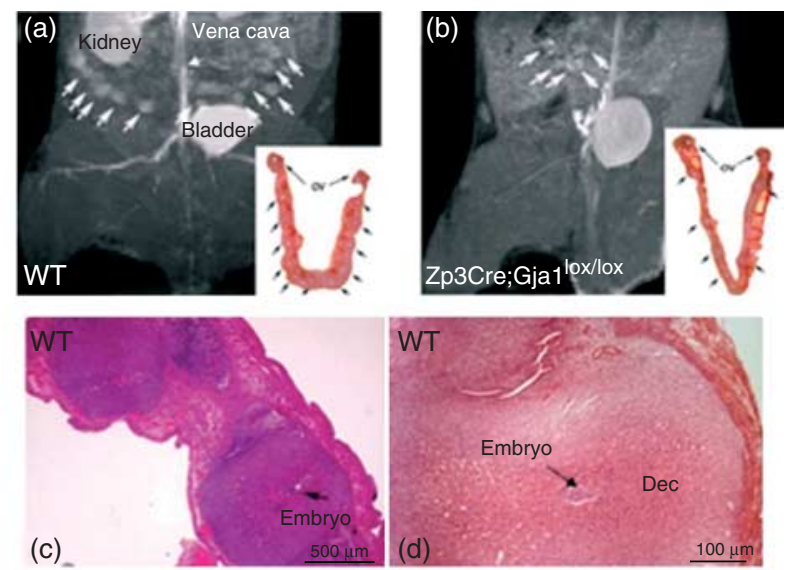

Zp3Cre;Gja1 ${ }^{\text {lox/lox }}$

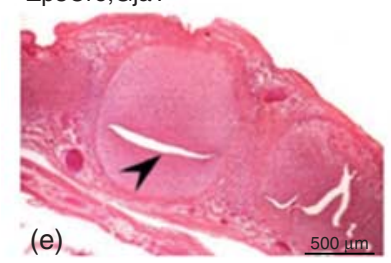

Zp3Cre;Gja1 ${ }^{\text {lox/lox }}$

(g)
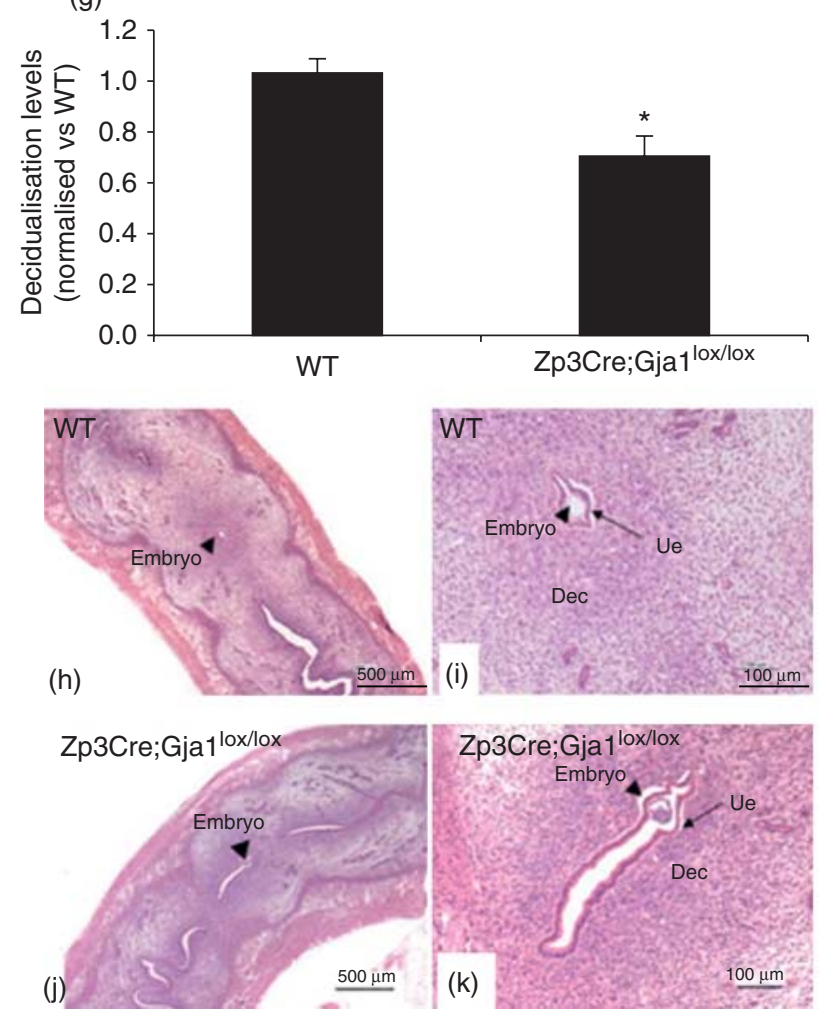

PCR

The cDNAs generated by the protocol mentioned earlier were used for PCR amplification, with primer sets for Cre-Zp3, Cx43, Gjb2 and $\beta$-actin (Table 1 ) in a $25 \mu \mathrm{l}$ reaction volume with $10 \mathrm{mM}$ Tris- $\mathrm{HCl}$ (pH 9.0), $50 \mathrm{mM} \mathrm{KCl,} 0.1 \%$ Triton X-100 (Promega), $2.5 \mathrm{mM} \mathrm{MgCl} 2,400 \mu \mathrm{M}$ each d-NTP and 0.625 units of Taq DNA Polymerase (Promega). The PCR was carried out by initial denaturation at $94{ }^{\circ} \mathrm{C}$ for $3 \mathrm{~min}$, then $20-35$ cycles at $94{ }^{\circ} \mathrm{C}$ for $1 \mathrm{~min}$ followed by $55^{\circ} \mathrm{C}$ for $1 \mathrm{~min}, 72{ }^{\circ} \mathrm{C}$ for $1 \mathrm{~min}$, and a final incubation at $72{ }^{\circ} \mathrm{C}$ for $7 \mathrm{~min}$. The number of cycles used ensured that the reaction could be quantified within the log phase of the amplification reaction.

The reaction mix $(24 \mu \mathrm{l})$ was run on a $1.5 \%$ agarose gel stained with ethidium bromide and quantified using UV imaging (Gel Doc 1000, Bio-Rad) and Molecular Analyst software (Bio-Rad). Each sample was analysed in triplicates. Band density of $C \times 43$ and Gjb2 was quantified using the ImageJ software.

\section{Embryo collection and transfer}

For the recovery of eight-cell embryos, superovulated females mated with males and examined for vaginal plugs the following morning (0.5 days post-coitum, d.p.c), were killed on 2.5 d.p.c. The blastocysts, developed in vitro after $24 \mathrm{~h}$ of incubation, were transferred to the uteri of 2.5 d.p.c pseudopregnant females (8-10 blastocysts per uterine horn). At the end of pregnancy, the number of neonates was monitored.

\section{Isolation and hybridisation of RNA for microarray analysis}

For isolation of RNA from oocytes, blastocysts and implantations site, the PerfectPure RNA Cultured Cell Kit (5 Prime, Hamburg, Germany) including DNase 1 digestion and depleted of rRNA was used. Two different pools of samples from each experimental group were processed as recommended by the manufacturer.

Figure 1 Characteristics of the implantation disorder of embryos originating from Zp3Cre; Gja1 ${ }^{\text {lox/lox }}$ oocytes. Dynamic contrast-enhanced Magnetic resonance imaging DCE-(MRI) of pregnant female mice on E5.5. Representative MRI images show fewer implantation sites (indicated by arrows) in Zp3Cre;Gja1 lox/lox (b) compared with WT (a) mice. Arrowheads in figures $1 \mathrm{a}$ and $\mathrm{b}$ indicate implantation sites. The number of implantation sites correlates well with that detected ex vivo (inserts) ov, ovaries ( $n=3$ females of each genotype). Representative images of histological longitudinal sections of implantation sites recovered from pregnant WT (c and d, $n=4$ ) and Zp3Cre;Gja $1^{\text {lox/lox }}$ (e and f, $n=5$ ) mice on E5.5. Note that in Zp3Cre;Gja $1^{\text {lox/lox }}$ females decidualisation is weak (e). Arrowhead in figure $1 \mathrm{e}$ indicate weak decualidation and embryo resorptions are observed (f). Arrowhead in figures $1 \mathrm{f}$ indicate resorption site. dec, decidua; res, resorption. Quantification of decidualisation in Zp3Cre;Gja ${ }^{\text {lox/lox }}$ compared with WT mice (g). Asterick in figure $1 \mathrm{~g}$ indicate significant difference between WT and Zp3Cre; Gja1 lox/lox $(P<0.05)$. Histological longitudinal section of implantation sites of $\mathrm{E} 4.5$ WT (h and $\mathrm{i}, n=11$ and Zp3Cre;Gja1 ${ }^{\text {lox/lox }}(\mathrm{j}$ and $\mathrm{k}, n=4$ ) mice.

Arrowhead in figures $1 c, d, h, i, j, k$ indicate embryo. Note that the Zp3Cre;Gja1 ${ }^{\text {lox/+ }}$ embryo has a delayed implantation phenotype, as no implantation chamber has formed, decidualisation is weak and embryo is in the blastocyst stage (j). dec, decidua; ue, uterine epithelium. Size bars for $c, e, h, j=500 \mu \mathrm{m}$, size bar for $d, f, i, k=100 \mu \mathrm{m}$. 

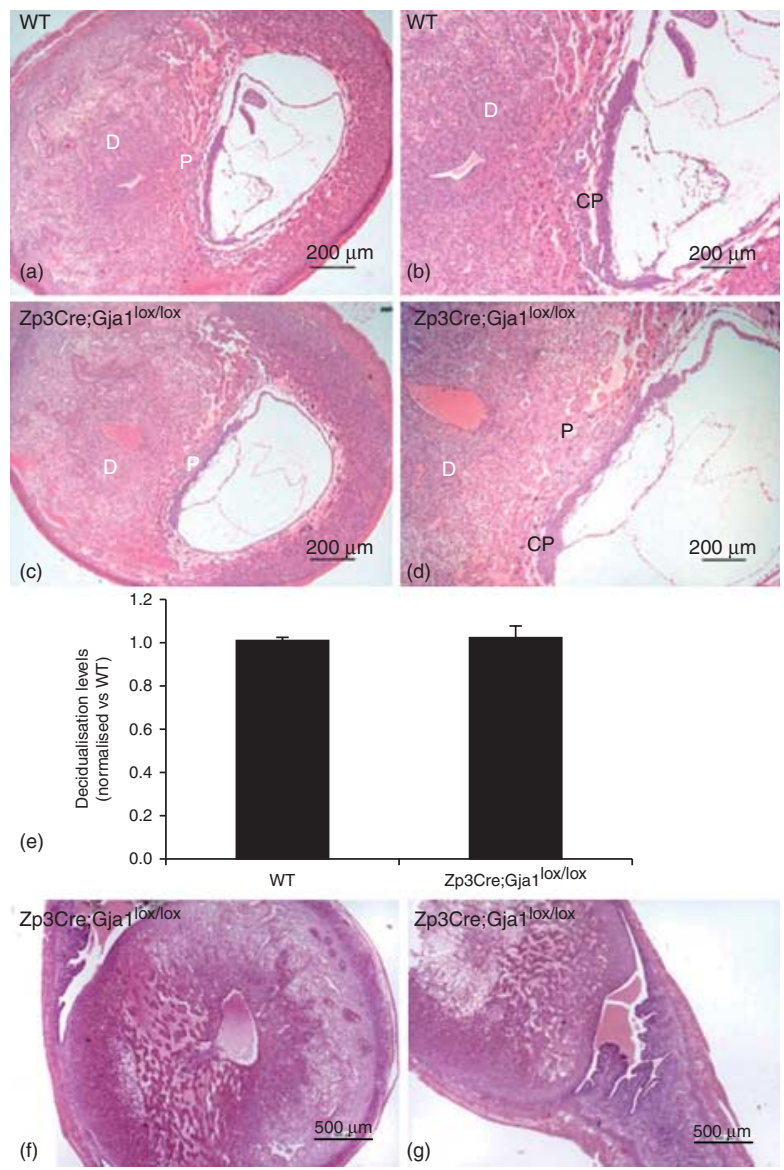

Figure 2 Histological characteristics of E9.5 WT vs Zp3Cre;Gja1 lox/lox implantation sites. Representative images of a longitudinal section of implantation sites of WT ( $\mathrm{a}$ and b) and Zp3Cre;Gja1 ${ }^{\text {lox/lox }}$ (c and d) pregnant mice at day E9.5 that appear normal as demonstrated by quantification analysis of decidualisation in WT and Zp3Cre;Gja1 ${ }^{\text {lox/lox }}$ (e), except for resorptions in the $\mathrm{Zp3Cre;Gja1} 1^{\text {lox/lox }}$ ( $\mathrm{f}$ and $\mathrm{g}$ ). D, decidua; $\mathrm{P}$, placenta; $\mathrm{CP}$, chorionic plate. Number of implantation sites detected was $12(4+8)$ in 2 Zp3Cre;Gja1 ${ }^{\text {lox/lox }}$ females vs $28(16+12)$ in two WT females. Scale bars: Figures $a, b, c$ and $d=200 u m$, Figures $\mathrm{f}$ and $\mathrm{g}=500 \mathrm{um}$.

\section{Microarray data processing and analysis}

The expression levels of mRNA in MII oocytes, blastocysts and implantation site from WT and Zp3Cre;Gja1 ${ }^{\text {lox/lox }}$ females were measured. Total RNA was isolated and hybridised on Affymetrix Mouse Genome 430 2.0 Arrays. CEL files extraction summarisation and normalisation were done by MAS5 algorithm ( $R$ microarray suite) followed by Lowess normalisation for each time point separately. The value 5 (log base 2 scale) was defined as the threshold for signal intensity. Significantly expressed genes were identified using z-test and FDR correction by estimation of the measured noise as described previously (Zeisel et al. 2010). The microarray data can be downloaded from Gene Expression Omnibus Accession number GSE35299.

\section{Quantitative PCR}

All real-time PCR analyses were carried out on a Rotor-Gene 3000 (Corbett Research, Sydney, NSW, Australia), using the
Absolute QPCR Master Mix (ABgene, Surrey, UK) with SYBR Green. Reaction protocols had the following format: $15 \mathrm{~min}$ at $95{ }^{\circ} \mathrm{C}$ for enzyme activation, followed by 40 cycles of $15 \mathrm{~s}$ at $95^{\circ} \mathrm{C}, 30 \mathrm{~s}$ at $60^{\circ} \mathrm{C}$ and $15 \mathrm{~s}$ at $72{ }^{\circ} \mathrm{C}$, at the end of fluorescence was measured with the Rotor-Gene. SYBR Green I assays also included a melt curve at the end of the cycling protocol, with continuous fluorescence measurement from 65 to $99^{\circ} \mathrm{C}$. All reactions contained the same amount of cDNA, $10 \mu \mathrm{l}$ Absolute QPCR Master Mix, primers for the indicated genes (Table 2) and UltraPure PCR-grade water (Fisher Biotec, Subiaco, WA, Australia) to a final volume of $20 \mu \mathrm{l}$.

Each real-time PCR analysis included a no-template control as well as five or six serial fourfold dilutions, in duplicate, of a cDNA pool containing all experimental samples of the respective tissue. The prenormalised DNA quantity of each gene in every sample was estimated relative to this dilution series. This dilution series also served to assess the reaction performance $\left(\mathrm{E}\right.$ and $\left.r^{2}\right)$. The threshold cycle $(C t)$ was set so as to obtain the highest reaction efficiency and correlation coefficient.

\section{Statistical analysis}

Each experiment was carried out at least three times, with samples pooled from at least three to four mice. Data points are presented as mean \pm s.E.M. Statistical significance was evaluated using Student's two-tailed unpaired t-test (Microsoft Excel).

\section{Results}

\section{Characteristics of the implantation disorder of embryos originating from $\mathrm{Cx}_{4} 3^{\text {del/del }}$ oocytes}

Our previous study (Gershon et al. 2008b) showed that Zp3Cre;Gja1 lox/lox females mated with WT males, produce a reduced number of embryos which traces back to a failure at the stage of embryo implantation. In the present study, using conventional ex-vivo examination, after i.v. injection of Evans blue, complemented by macromolecular dynamic contrast-enhanced magnetic resonance imaging (DCE-MRI; Plaks et al. 2006), we wished to further map this subfertility to a particular stage of implantation. For this purpose, we employed a macromolecular MR-contrast material that selectively extravagates from areas of high permeability, allowing non-invasive detection of implantation sites, which was followed by a detailed histological examination.

Our previous report showed a significant reduction in the number of implantation sites in Zp3Cre;Gja1 ${ }^{\text {lox/lox }}$ females compared with WT (Gershon et al. 2008b). We extended this study demonstrating herein that an average of six implantation sites is detected by dynamic contrastenhanced magnetic resonance imaging (DCE-MRI; Plaks et al. 2006) in a E5.5 Zp3Cre;Gja1 lox lox pregnant mice compared with 11 in the WT (Fig. $1 \mathrm{a}$ and b, $n=3$ ). The data generated by MRI correlate well with that obtained by ex vivo analysis of the same mouse after i.v. injection of Evans blue (Fig. 1a and b, inserts). 
Upon examination of uterine histological sections, a heterogeneous phenotype was found as follows. At E5.5, the WT decidua was expanded (Fig. $1 \mathrm{c}$ and d, $n=12$ ) while in the $\mathrm{Zp} 3 \mathrm{Cre}$; Gja $1^{\text {lox/lox }}$ decidualisation was $70 \%$ weaker (this phenotype was observed across implantations sites
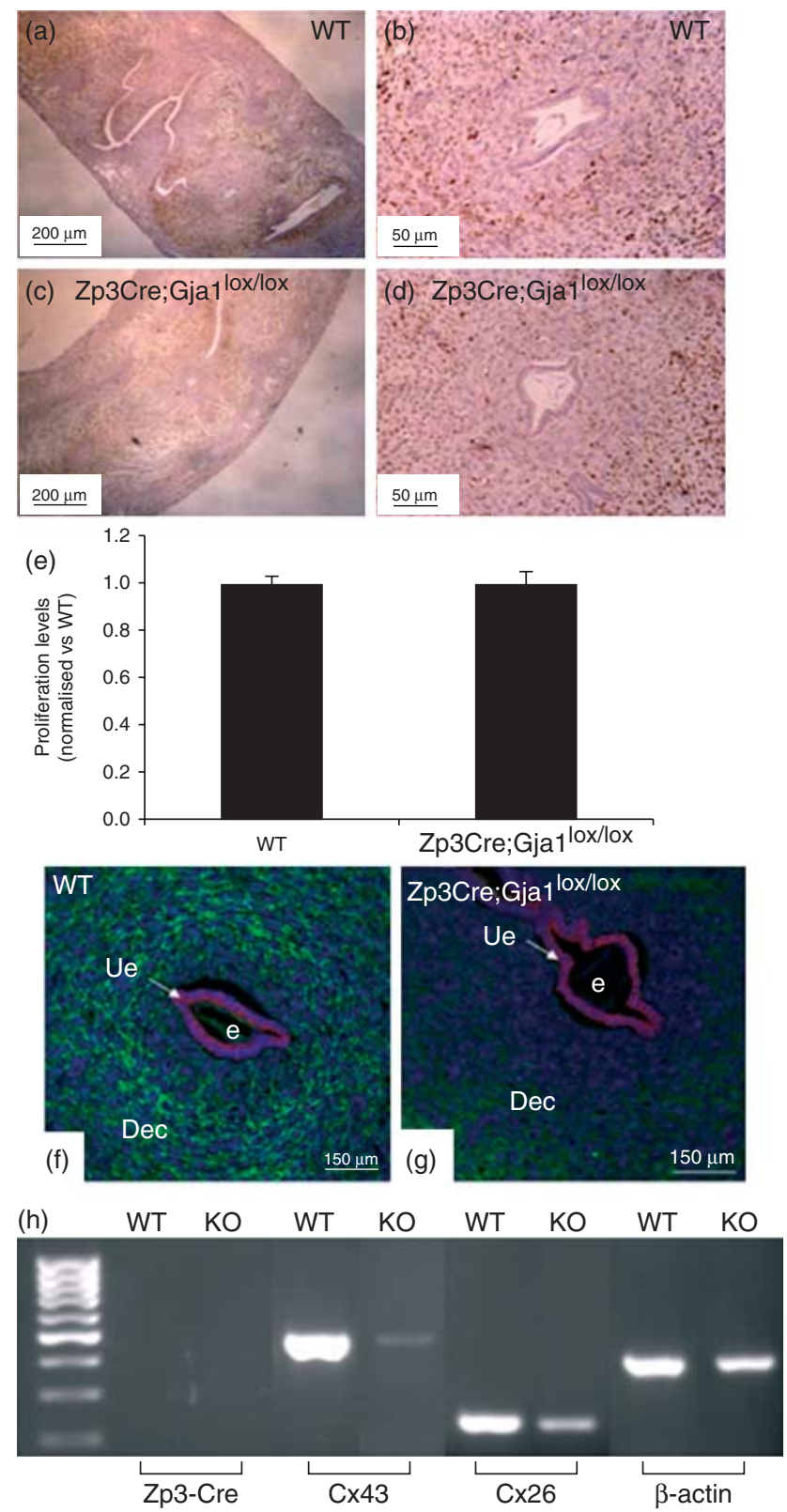

(i)

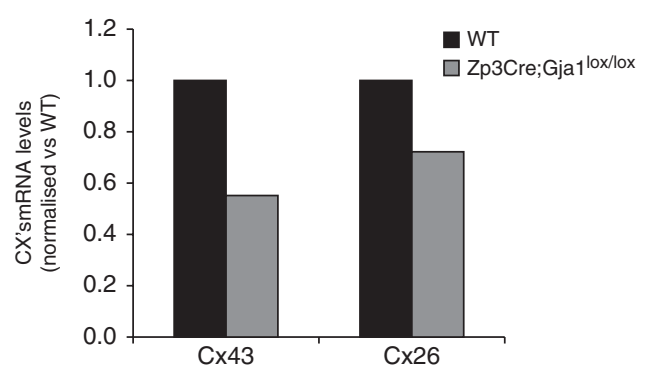

in four out of four females, Fig. 1e, f and g). Moreover, resorptions were observed in the $\mathrm{Zp} 3 \mathrm{Cre} ; \mathrm{Gja} 1^{\text {lox/lox }}$ (this phenotype was observed across implantations sites in five females, Fig. 1f). In addition, in the E4.5 WT mice, the embryos reached the egg cylinder stage and the stromal tissue proliferated and differentiated into the decidua (Fig. $1 \mathrm{~h}$ and $\mathrm{I}$, this phenotype was observed across implantations sites in four out of four females). On the other hand, implantation sites of Zp3Cre;Gja1 lox/lox females, examined at E4.5, exhibited weak decidualisation, no implantation chamber and embryos that were still in their blastocyst stage (this phenotype was observed across implantations sites in four females, Fig. $1 \mathrm{j}$ and k). On E9.5 (Fig. 2), the reduction in the number of Zp3Cre;Gja1 $1^{\text {lox/lox }}$ implantation sites vs WT was maintained. In both WT (Fig. 2a and b) and Zp3Cre;Gja ${ }^{\text {loxlox }}$ (Fig. 2c and d), existing implantation sites looked normal (Fig. 2e), although histological sections revealed that some of the embryos in the Zp3Cre;Gja1 ${ }^{\text {lox/lox }}$ were going through resorption (Fig. 1E, $f$ and g). In Zp3Cre;Gja1 ${ }^{\text {lox/lox }}$ females, the embryos that appears normal probably proceeded till birth as no defects were observed in Zp3Cre;Gja1 $1^{\text {lox/+ }}$ neonates (three pups in each group were visually examined and two pups in each group, male and female, had their vital organs examined for possible pathologies in histological sections, data not shown).

\section{Decidual proliferation is intact but decidual differentiation is impaired in $\mathrm{Zp3Cre;Gja1^{lox } / l o x}$ implantation sites}

As can be seen using immunostaining with Ki67, proliferation of stromal tissue (as it converts into the decidua) was not significantly different between WT

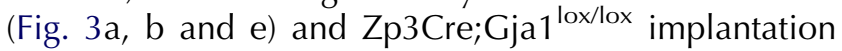
sites (Fig. 3c, d and e),

The expression of specific Cxs in the endometrium is one of the earliest physiological changes derived from

\footnotetext{
Figure 3 Decidual differentiation is impaired in Zp3Cre;Gja $1^{\text {lox/lox }}$ implantation sites. Representative images of immunostaining of Ki67 (brown) show no difference in proliferation of stromal tissue (as it converts to the decidua) between implantation sites of E4.5 WT (a and $\mathrm{b}$, a total of three mice with an average of 11 implantation sites per female) vs Zp3Cre;Gja1 ${ }^{\text {lox/lox }}$ mice (c and d, a total of three mice with six implantation sites per female). Quantification of proliferation in Zp3Cre;Gja1 ${ }^{\text {lox/lox }}$ compared with WT mice (e). Representative images of confocal microscopy of E4.5 implantation sites sections show a substantial decrease in Cx43 expression (green) in the decidua and in Gjb2 (red) expression in the uterine epithelium of Zp3Cre;Gja $1^{\text {lox/lox }}(\mathrm{f})$ compared with WT females (g). Nuclei are stained with TO-PRO-3 (blue). e, embryo; ue, uterine epithelium; dec, decidua. Size bars for a, $c=200 \mu \mathrm{m}$, for $\mathrm{b}, \mathrm{d}=50 \mu \mathrm{m}$ and for $\mathrm{f}, \mathrm{g}=150 \mu \mathrm{m}$. RT-PCR analysis of Cx43, Gjb2 Zp3-Cre recombinase and $\beta$-actin (h and i) in implantation sites of WT and KO samples (recovered from Zp3Cre;Gja $1^{\text {lox/lox }}$ mice). The results of one representative out of a total of three independent experiments (each including a pool of implantation sites from three mice) with similar results are presented.
} 
Table 3 Reciprocal embryo transfer.

\begin{tabular}{|c|c|c|c|c|}
\hline \multicolumn{2}{|r|}{ Females } & \multicolumn{2}{|r|}{ Pups } & \multirow{2}{*}{$\begin{array}{c}\text { Average } \\
\text { (pups/female) }\end{array}$} \\
\hline No. & Genotype & No. & Genotype & \\
\hline 5 & WT & 1 & Zp3Cre;Gja1 lox/lox & 0.2 \\
\hline 5 & Zp3Cre;Gja1 $1^{\text {lox/lox }}$ & 27 & WT & 5.4 \\
\hline
\end{tabular}

Three independent experiments.

foeto-maternal interactions (Winterhager et al. 1993). Therefore, the expression of $C_{x} 43$ in the decidua and that of $C \times 26$ in the uterine epithelium was examined (Fig. $3 f$ and g). The expression of $C \times 43$ mRNA in the decidua was reduced by $50 \%$ in Zp3Cre;Gja $1^{\text {lox/lox }}$ compared with WT females (Fig. $3 \mathrm{~h}$ and i). There was also a 30\% reduction in Cx26 expression in Zp3Cre;Gja1 ${ }^{\text {lox/lox }}$ females compared with WT (Fig. $3 \mathrm{~h}$ and i). Note that $C \times 43$ reduction was not due to a non-specific expression of Cre recombinase in the implantation sites (Fig. 3h, first two lanes).

\section{Defects in the embryo rather than in the mother are responsible for the implantation disorder in the Zp3Cre;Gja $1^{\text {lox/lox }}$ females}

To further substantiate the crucial factor that causes implantation failure, reciprocal embryo transfer experiments were carried out: Zp3Cre;Gja1 ${ }^{\mathrm{lox} /+}$ embryos were transferred to WT females and vice versa. These experiments revealed that $\mathrm{Zp} 3 \mathrm{Cre} ; \mathrm{Gja} 1^{\text {lox/lox }}$ females bearing WT embryos gave birth to normal litters as compared with the poor birth rate obtained in the reciprocal experiment $(n=5$ females for each experimental group in three independent experiments, Table 3).

\section{Gene expression analysis of the Zp3Cre;Gja $1^{l o x / l o x}$ model suggests that the implantation failure of the resulting blastocysts is associated with impaired ribosomal and translational machinery}

In order to identify the components of the oocyte molecular machinery that take part in the production of a healthy embryo, we screened the transcriptome in the Zp3Cre;Gja1 ${ }^{\text {lox/lox }}$ model (KO) vs the control (WT). The experimental design included sampling of RNA of ovulated oocytes arrested at MII ( $n=120$ per replicate), early blastocysts (washed from the uterus just before implantation, $n=37$ per replicate) and E5.5 implantation sites (consisting of the implanted embryos surrounded by maternal uterine tissue, $n=4-5$ per replicate from three mice per biological replicate) (Fig. 4a). The data was analysed to find differentially expressed genes by comparing the WT and $\mathrm{KO}$ samples in each tissue (oocytes, blastocysts, and implantation sites). A general view at the data set using principal component analysis (PCA) shows the differences between the various samples analysed. This analysis revealed that the largest difference between our KO model and WT seems to be in the blastocysts samples (Fig. 4b). After identifying the differentially expressed genes, we used DAVID web tool (Huang da et al. 2009) for enrichment analysis. The differentially expressed genes in each tissue were divided into either upregulated $(\mathrm{KO}>\mathrm{WT})$ or downregulated $(\mathrm{KO}<\mathrm{WT})$ genes, and then analysed for enrichment of biological processes and pathways (Fig. 5). Importantly, we noticed the involvement of translation-related events (e.g. ribosomes) as well as metabolic-related processes in the MII oocytes and blastocysts. Since the implantation sites represent mostly maternal tissue, which was shown not to be the detrimental factor in the implantation disorder of the Zp3Cre;Gja1 ${ }^{\text {lox/lox }}$ blastocysts, the number of differentially expressed genes was smaller between $\mathrm{KO}$ and WT in these samples and enrichment analysis shows no significance.

A significant down regulation of transcripts related to translation, such as ribosomal proteins and eukaryotic translation initiation factors (EIFS), was found mainly in the Cx43 del/del $(K O)$ MII oocytes as well as in the resulting blastocysts. This was accompanied by a significant global reduction in the gene expression of the $\mathrm{C} \times 43^{\mathrm{de} / \mathrm{del}}(\mathrm{KO})$ MII oocytes and the resulting blastocysts, indicating a major impairment of the translational machinery.

Real-time quantitative PCR was carried out to validate specific candidates of the differentially expressed genes. This analysis revealed that Egr1, Rp/21 and Eif4a1 were significantly downregulated in the $\mathrm{C} \times 43^{\mathrm{del} / \mathrm{del}}$ MII oocytes (Fig. 6a, Egr1 P=0.0047, Rp/21 $P=7.5 \times 10^{-4}$,
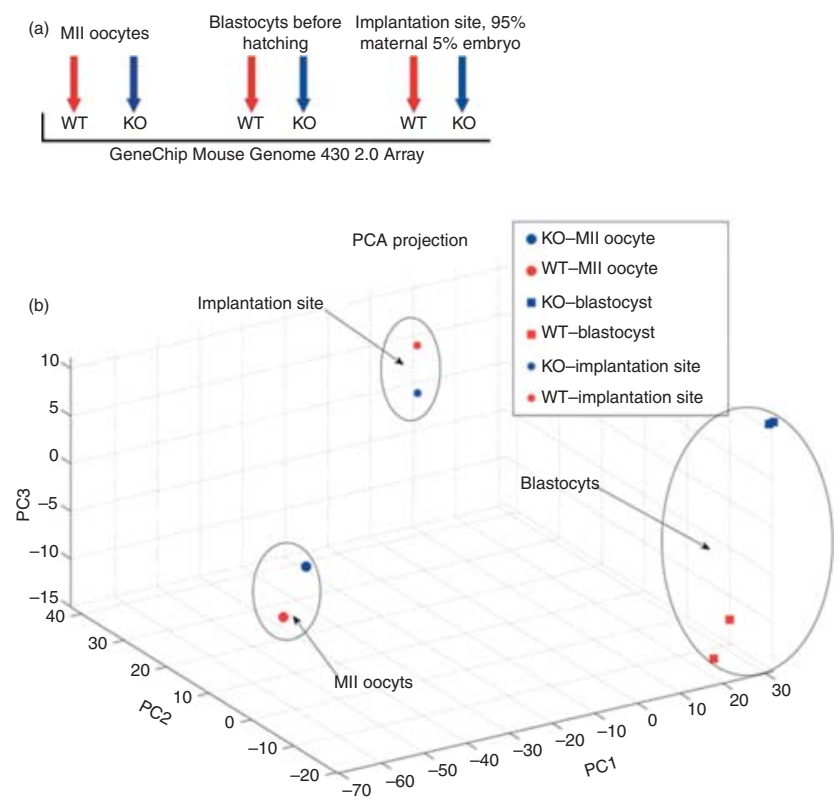

Figure 4 cDNA microarray gene expression analysis of the Zp3Cre;Gja ${ }^{\text {lox/lox }}$ model. Experimental design (a) and a general view at the dataset using principal component analysis (PCA) a technique used to reduce multidimensional data sets to lower dimensions (b). $\mathrm{KO}$ - samples recovered from the $\mathrm{Zp} 3 \mathrm{Cre} ; \mathrm{Gja} 1^{\text {lox/lox }}$ mouse model. 
(a)

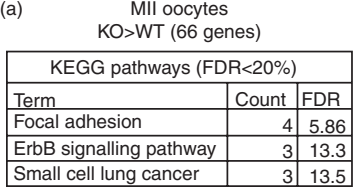

(b)

(b) KO $>$ WT (158 genes)
\begin{tabular}{|l|r|r|}
\hline \multicolumn{3}{|c|}{ KEGG pathways (FDR $<20 \%)$} \\
\hline Term & Count & FDR \\
\hline Ribosome & 10 & $1.78 \mathrm{E} .004$ \\
\hline \multicolumn{3}{|c|}{} \\
\hline GO biological processes (FDR $<5 \%$ ) \\
\hline Term & Count & FDR \\
\hline Metabolic process & 77 & 0.021391 \\
\hline Macromolecule metabolic process & 64 & 0.086248 \\
\hline Cellular metabolic process & 70 & 0.095262 \\
\hline Cellular biosynthetic process & 19 & 0.203011 \\
\hline Translation & 13 & 0.339693 \\
\hline Gene expression & 39 & 0.363727 \\
\hline Primary metabolic process & 68 & 0.468728 \\
\hline Macromolecule biosynthetic process & 15 & 1.095997 \\
\hline Biosynthetic process & 20 & 2.496638 \\
\hline
\end{tabular}

(c)

KO>WT (241 genes)
\begin{tabular}{|l|r|r|}
\hline \multicolumn{3}{|c|}{ KEGG pathways (FDR<20\%) } \\
\hline Term & Count & FDR \\
\hline Ribosome & 7 & 3.97 \\
\hline TGF- $\beta$ s signaling pathway & 6 & 17.4 \\
\hline Type I diabetes mellitus & 5 & 17.7 \\
\hline \multicolumn{3}{|c|}{ GO biological processes (FDR $<5 \%$ ) } \\
\hline Term Count & FDR \\
\hline Metabolic process & 107 & 0.04 \\
\hline Primary metabolic process & 98 & 0.08 \\
\hline Biosynthetic process & 30 & 0.09 \\
\hline Translation & 17 & 0.11 \\
\hline Macromolecule biosynthetic process & 21 & 0.13 \\
\hline Cellular biosynthetic process & 24 & 0.26 \\
\hline Cellular metabolic process & 96 & 0.32 \\
\hline Cellular macromolecule metabolic process & 51 & 0.76 \\
\hline Protein metabolic process & 52 & 0.87 \\
\hline Cellular protein metabolic process & 50 & 1.05 \\
\hline Macromolecule metabolic process & 83 & 2.9 \\
\hline
\end{tabular}

(d)

\begin{tabular}{|l|r|r|}
\hline \multicolumn{3}{|c|}{ KEGG pathways (FDR<20\%) } \\
\hline Term & Count & FDR \\
\hline Ribosome & 6 & 6.8 \\
\hline \multicolumn{3}{|c|}{} \\
\hline GO biological processes (FDR $<5 \%$ ) \\
\hline Term & Count & FDR \\
\hline Primary metabolic process & 110 & 0.01 \\
\hline Cellular biosynthetic process & 29 & 0.01 \\
\hline Cellular metabolic process & 106 & 0.11 \\
\hline Metabolic process & 114 & 0.19 \\
\hline GO: 0019538-protein metabolic process & 57 & 0.49 \\
\hline Cellular protein metabolic process & 54 & 0.99 \\
\hline Translation & 16 & 1.06 \\
\hline DNA metabolic process & 19 & 1.08 \\
\hline Biosynthetic process & 29 & 1.14 \\
\hline Cellular macromolecule metabolic process & 54 & 1.37 \\
\hline Macromolecule metabolic process & 91 & 1.89 \\
\hline Ubiquitin cycle & 15 & 2.61 \\
\hline Purine nucleotide biosynthetic process & 6 & 4.49 \\
\hline
\end{tabular}

(e) Implantation sites

KO>WT (53 genes)

\begin{tabular}{|l|r|c|}
\hline \multicolumn{3}{|c|}{ KEGG pathways (FDR<20\%) } \\
\hline Term & Count & FDR \\
\hline Oxidative phosphorylation & 4 & 0.71717 \\
\hline
\end{tabular}

(f)

KOWT (53 genes)
Non significant

Figure 5 Enrichment analysis of significantly differentially expressed genes (FDR, false discovery rate). Genes upregulated (KO $<\mathrm{WT})$ or downregulated $\left(\mathrm{KO}<\mathrm{WT}\right.$ ) in MII oocytes ( $\mathrm{a}$ and b), blastocysts ( $\mathrm{c}$ and $\mathrm{d}$ ) and implantation sites (e and $\mathrm{f}$ ) in Zp3Cre;Gja $1^{\text {lox/lox }}$ model as compared to control littermates. and then analysed for enrichment of biological processes and pathways.

Eif4a1 $P=0.0024)$ and that Rp/15 and Eif4g2 were significantly downregulated in Zp3Cre;Gja1 $1^{\text {loxllox }}$ blastocysts (Fig. 6 b, Rpl15 $P=0.048$, Eif4g2 $P=0.042$ ). The differences in expression levels shown by the PCR confirmed those found in the array analysis.

We also decided to trace back the findings concerning impaired translation to the point of $C \times 43$ deletion by the $Z p 3-C r e$, i.e. day 3 postnatal. We therefore compared ovaries from neonates on postnatal days 2-3, 5 and 15 with ovaries of 25-day-old female mice after hormonal stimulations and postovulation, as well as to the ovulated MII oocytes. First, we verified that $C_{x} 43$ is not expressed along all the developmental stages tested (Fig. 6c). Next, we examined the expression levels of Rps6, a major ribosomal protein. We found that a significant reduction in this transcript was already exhibited very early, at days 2-3 postnatal and persisted with time till day 15 (Fig. 6d, days $2-3 P=0.0098$, day $5 P=0.013$, day $15 P=0.01, n=4$ per days $2-3$ and 5 and $n=8$ per day 15 ). Postovulatory ovaries isolated from Zp3Cre;Gja1 ${ }^{\text {lox/lox }}$ females exhibited similar levels of Rps6 compared with WT ovaries, but MII oocytes isolated from these females ovaries still demonstrated low levels of this transcript as compared with WT MIl oocytes (Fig. 6d).

\section{Discussion}

We present herein a particular example of oocytes that undergo normal oogenesis according to standard morphological and functional parameters but give rise to defective blastocysts. We demonstrate, for the first time, that failure of blastocysts that originate from such oocytes to implant is apparently due to a critical shutdown in the translational and metabolic machineries.

Unlike the oocytes of the systemic Cx43 KO mice, which never expressed $C_{x} 43$, the deletion of $C x 43$ in our model occurs postnataly, around day 3, the age at which the $Z p 3$ gene is expressed and Cre recombinase is activated (Chaddha et al. 2004). Therefore, the oocytes and the ovarian follicle cells in our model do express Cx43 throughout prenatal life, as well as during the first 3 postnatal days, an age at which folliculogenesis proceeds to the primary stage (Epifano et al. 1995) (Schematic Fig. 7; red boxes mark stages of oocyte and embryonic development at which $C_{x 43}$ is present). Nevertheless, embryos originating from such oocytes exhibited implantation disorders. Our present findings combined with previous reports of the phenotype of systemic Cx43 KO (Juneja et al. 1999, Ackert et al. 2001) reveal that the time 

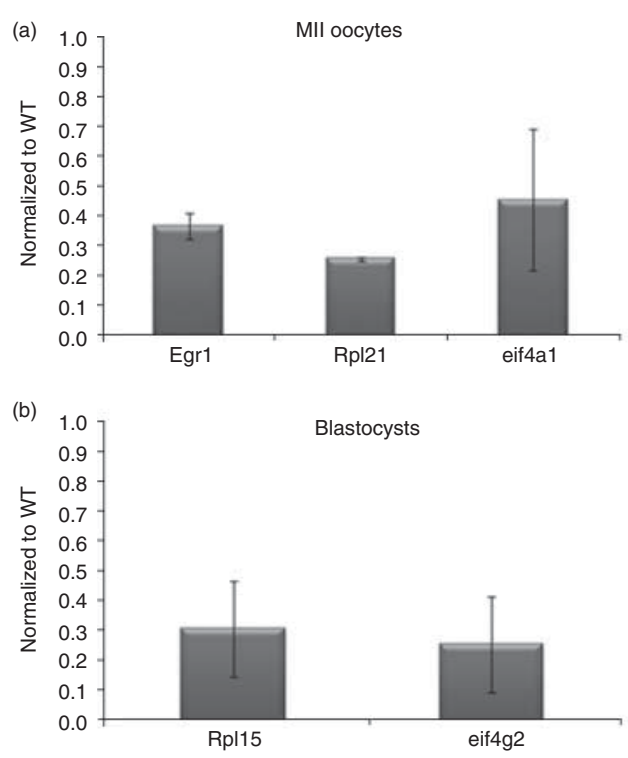

(c)
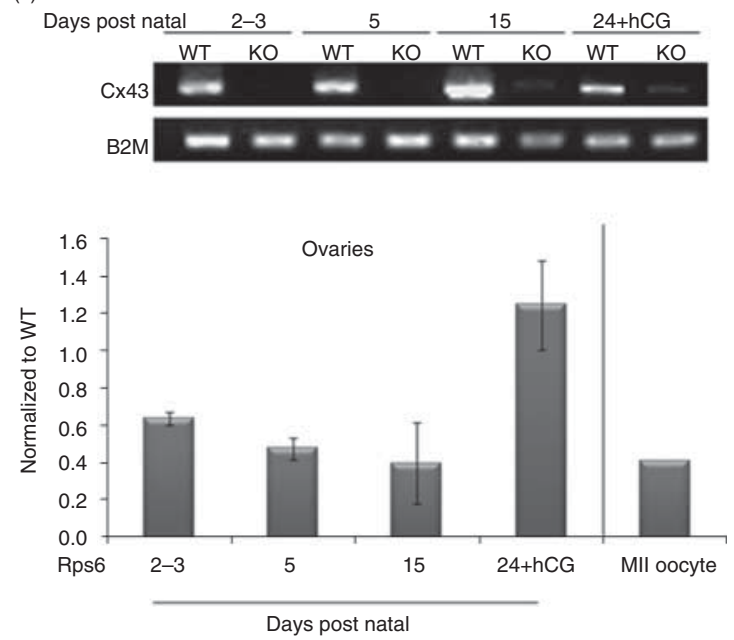

Figure 6 Verification of the microarray analysis of the Zp3Cre;Gja $1^{\text {lox/lox }}$ model. Quantitative PCR for differentially expressed genes. (a) Expression of Egr1, Rp/21, and Eif4a1 in Cx43 del/del (KO) compared with WT MII oocytes. (b) Expression of Rp/15 and Eif4g2 in Zp3Cre;Gja1 ${ }^{\text {lox/lox }}(\mathrm{KO})$ compared with WT blastocysts. The expression levels of the genes in $\mathrm{a}$ and $\mathrm{b}$ are presented in the $\mathrm{KO}$ relative to WT levels. (c) Expression of Cx43 in WT and Zp3Cre;Gja1 ${ }^{\text {lox/lox }}$ ovaries and $\mathrm{C} \times 43^{\mathrm{del} / \mathrm{del}}$ oocytes at different stages. (d) Expression of Rps6 in ovaries of 2-3, 5 and 15-day-old Zp3Cre;Gja $1^{\text {lox/lox }}$ neonates ovaries compared with postovulatory ovaries of WT mice as well as MII oocyte.

at which $\mathrm{Cx} 43$ depletion takes place plays a crucial role in the acquisition of developmental competence by the oocyte. The fact that the systemic Cx43 KO mice suffer a sever impairment of follicle development and retarded oocyte growth, whereas folliculogenesis and oogenesis in the Zp3Cre;Gja $1^{\text {lox/lox }}$ mice appear normal, is apparently attributable to the relatively delayed time point of $\mathrm{Cx} 43$ depletion in our model. Furthermore, this may be the reason that, unlike the oocytes recovered from the ovaries of the systemic $\mathrm{Cx} 43 \mathrm{KO}$, oocytes in our model resume meiosis, can be fertilised and successfully undergo early embryonic development. Nevertheless, this late depletion in follicular Cx43 still leads to subfertility, which in our case is manifested by the development of blastocysts that appear morphologically normal but exhibits retarded implantation abilities. On the contrary, a Cx43 KO embryo is a result of $\mathrm{Cx} 43$ heterozygous mating. Oocytes from such mating will loose the single copy of Cx43 only after the first polar body extrusion, which occurs much later than in the $\mathrm{Cx} 43 \mathrm{KO}$ oocytes recovered from the fetal ovaries of the systemic $\mathrm{Cx} 43 \mathrm{KO}$ and also later than in the Zp3Cre;Gja1 loxlox model presented here. The outcome of the oocyte from a heterozygous Cx43 mating, even though fertilised by a sperm already missing the single Cx43 copy, is still far better, as evidenced by the fact that the resulting foetus proceeds throughout pregnancy and dies from cardiac malfunction at birth (Reaume et al. 1995). Table 4 summarises these differences between the various models. This table shows that the time at which Cx43 depletion takes place plays a crucial role in the acquisition of developmental competence by the oocyte.

Most importantly, we show herein that the apparently normal Cx43 $3^{\mathrm{del} / \mathrm{del}}$ MII oocytes, as well as the resulting blastocysts exhibit global perturbations in the profile of transcripts regulating protein synthesis. Transcripts and proteins of the oocyte may be involved in cellular processes critical for successful development of the embryo before and after activation of the zygotic genome. For example, blastocyst formation in the mouse is dependent on oocyte transcripts and proteins (De Sousa et al. 1998), generated during the growth phase, that function after fertilisation to support and regulate preimplantation embryonic development. In fact, in vitro matured human and bovine oocytes have been shown to have reduced protein content compared with in vivo matured oocytes (Trounson et al. 2001), suggesting that proteins play a critical role in the acquisition of developmental competence (Baird et al. 2005).

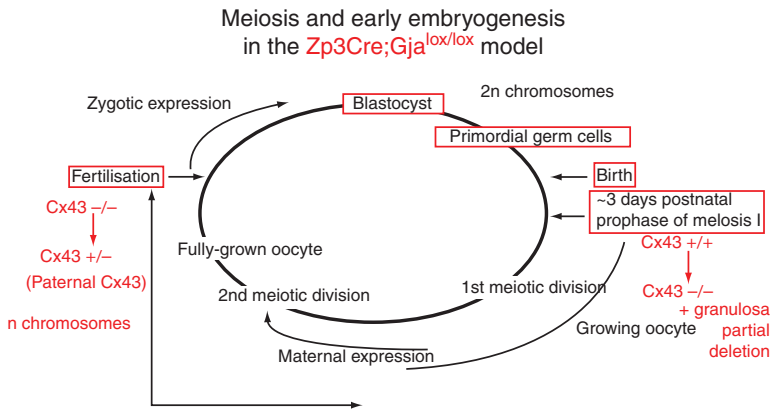

Figure 7 Meiosis and early embryonic development in the Zp3Cre;Gja1 ${ }^{\text {lox/lox }}$ model. The deletion of CX43 in the oocytes in our model occurs only at day 3 postnatal. During embryonic development all oocytes in our model express $C x 43$. Red boxes mark stages of oocyte and embryonic development at which $C_{x} 43$ is present in the Zp3Cre;Gja1 $1^{\text {lox/lox }}$ model. 
Table 4 Differences between the various Cx43 knockout models and the Zp3;Gja1 lox/lox .

\begin{tabular}{|c|c|c|c|c|c|}
\hline & $\begin{array}{l}\text { Systemic (ex vivo) } \\
\text { (Juneja et al. 1999, } \\
\text { Ackert et al. 2001) }\end{array}$ & $\begin{array}{l}\text { Chimera (Gittens \& } \\
\text { Kidder 2005) }\end{array}$ & $\begin{array}{l}\text { Chimera (Gittens \& } \\
\text { Kidder 2005) }\end{array}$ & $\begin{array}{l}\text { Oocyte-directed } \\
\text { (Zp3Cre;Gja1 } 1^{\text {lox/lox }} \text { ) } \\
\text { (Gershon et al. 2008b) }\end{array}$ & $\begin{array}{l}\text { Systemic } \\
\text { (Reaume et al. 1995) }\end{array}$ \\
\hline \multirow{2}{*}{$\begin{array}{l}\text { Genotype (Cx43 KO } \\
\text { localisation) }\end{array}$} & Oocyte - KO & Oocyte - WT & Oocyte - KO & Oocyte - KO & Oocyte - KO \\
\hline & Granulosa - KO & Granulosa - KO & Granulosa - WT & Granulosa - 88\% KO & Granulosa - HET \\
\hline $\begin{array}{l}\text { Time window }(\mathrm{CX} 43 \\
\mathrm{KO} \text { start time) }\end{array}$ & $\begin{array}{l}\text { Premordial germ cells } \\
\quad(\text { E11.5) }\end{array}$ & $\begin{array}{l}\text { Premordial germ cells } \\
\text { (E11.5) }\end{array}$ & $\begin{array}{l}\text { Premordial germ cells } \\
\text { (E11.5) }\end{array}$ & $\begin{array}{l}\text { Growing oocytes } \\
\quad(3-5 \text { days postnatal) }\end{array}$ & $\begin{array}{l}\text { Ml oocytes (sexual } \\
\text { maturation } \\
\sim 42 \text { days postnatal) }\end{array}$ \\
\hline \multirow[t]{2}{*}{ Ovarian phenotype } & $\begin{array}{l}\text { Oocyte - small; failed } \\
\text { to resume meiosis }\end{array}$ & $\begin{array}{l}\text { Oocyte }- \text { small; failed } \\
\text { to resume meiosis }\end{array}$ & Oocyte - normal & Oocyte - normal & Oocyte - normal \\
\hline & $\begin{array}{l}\text { Granulosa -primary } \\
\text { follicle }\end{array}$ & $\begin{array}{l}\text { Granulosa - preantral } \\
\text { follicle }\end{array}$ & Granulosa - normal & Granulosa - normal & Granulosa - normal \\
\hline Embryonic phenotype & No embryos & No embryos & $\begin{array}{l}\text { Two-cell embryos } \\
\text { (development } \\
\text { beyond this stage is } \\
\text { not indicated) }\end{array}$ & $\begin{array}{l}50 \% \text { - blastocysts lost } \\
\text { at hatching } \\
20 \% \text { - lost till birth } \\
30 \% \text { - born normal }\end{array}$ & $\begin{array}{l}\text { Neonates (die few days } \\
\text { postnatal) }\end{array}$ \\
\hline $\begin{array}{l}\text { Time line of embryonic } \\
\text { development }\end{array}$ & E0 & & & & Birth \\
\hline
\end{tabular}

$\mathrm{KO}$, knockout; HET, heterozygous.

Enrichment analysis of the differentially expressed genes in our present study indicated a strong perturbation in the translation/ribosomal machinery. One of the main genes examined in the oocytes that was found to be significantly reduced in the $\mathrm{Zp} 3 \mathrm{Cre} ; \mathrm{Gja} 1^{\text {lox/lox }}$ vs WT was early growth response 1 (Egr1). This gene was already shown to be critical to female fertility. Knocking out Egr1 gene in mice resulted in female infertility, although in this case it was due to LH deficiency in the pituitary (Lee et al. 1996). This gene was also shown to be induced in rat ovaries in response to an ovulatory dose of hCG (Espey et al. 2000) and to regulate the expression of the rat LH receptor gene (Yoshino et al. 2002). Moreover, granulosa cells Egr1 mRNA was previously identified to be associated with bovine oocyte developmental competence (Robert et al. 2001). These data suggest that the impaired acquisition of developmental competence observed in our study could possibly be attributed to Cx43 depletion-modulated Egr1 expression.

A significant reduction in numerous ribosomal proteins was exhibited in both oocytes and blastocyts. It was previously shown that ribosomal proteins have a substantial impact on the control of global gene expression and subsequent mouse embryonic development and that mutations in a single ribosomal protein may have detrimental effects (Kondrashov et al. 2011). Focusing on representative differentially downregulated candidates, we verified the expression of ribosomal protein $\mathrm{L}(R p) 21$ in the $\mathrm{Cx} 43^{\mathrm{del} / \mathrm{del}}(\mathrm{KO})$ MII oocytes and Rp/15 in the resulting blastocyts. Rp/21 mRNA is expressed during Xenopus embryogenesis and functions as a translational regulator (Loreni et al. 1992). Rp/15 is expressed during bovine meiotic maturation and embryogenesis. The mRNA of Rp/15 decreases during bovine oocytes meiotic maturation and increases in the morula and blastocyst stages of bovine embryogenesis (Bettegowda et al. 2006). This gene is upregulated in bovine follicular cystic ovaries and is probably responsible for the delayed regression with persistent follicle growth (Choe et al. 2010). We further suggest that Cx43 depletion modulate also ribosomal proteins expression affecting acquisition of developmental competence by the oocyte as well.

Along with the findings mentioned earlier, elF4 translation initiation factors were also differentially expressed in both $\mathrm{C} \times 43 \mathrm{KO}$ oocytes and in the resulting blastocyts. elF4 are effectors of mRNA recruitment to ribosomes and regulators of translation (Gingras et al. 1999). Eif4a1, which has an RNA helicase activity, and Eif4g2, which performs a ribosome/mRNA bridging function (Gingras et al. 1999), are representative for these regulators in oocytes and blastocysts, respectively. Both Eif4a 1 and Eif4g were found to be associated with the translation machinery in embryo divisions after fertilisation. Each of them is co-localised with the RNA-binding protein SAM68 in the zygote cytoplasm during translation inhibition (Paronetto et al. 2008) and plays roles in cell divisions (Hutchins et al. 2004). This data suggest that the reduced expression of the elF4 family members in the Cx43-depleted oocytes and the resulting blastocysts might disturb cell division, providing at least a partial explanation for the impaired fertility in Zp3Cre;Gja $1^{\text {lox/lox }}$ females.

The impaired developmental capacity of the C $\times 43^{\text {del/del }}$ oocytes can possibly represent the lack of Cx43 within the oocyte, as well as inadequate transfer of nutrients from the follicular somatic cells also partially depleted from $\mathrm{Cx} 43$. Actually, Cx43 has been shown as a major contributor to gap junctions in human cumulus cells and its expression level was positively correlated with intercellular conductance, embryo quality and pregnancy rate (Wang et al. 2009). Regulation of nutrient metabolism in the oocyte may be critical to create an environment supportive of nuclear and cytoplasmic maturation (Gardner et al. 2000). Glucose metabolism is essential in the control of meiosis in mouse oocytes (Downs 1995). Exposure of oocytes to elevated glucose concentrations during the 
maturation period may cause deleterious effects in the resulting embryo. High glucose levels during mouse preimplantation embryo development caused metabolic anomalies, resulting in diminished ATP stores, increased oxygen radicals, and altered gene expression, leading to apopotosis and malformations in the resulting foetus (Leunda-Casi et al. 2001). We also examined the expression of genes related to translation as well as to (glucose) metabolism during early ovarian and oocyte development (from days 2-3 postnatal, the time at which Cx43 is first depleted), such as ribosomal protein S6 (Rps6). A critical role of Rps6 in mouse embryo development is long established (Meyuhas 2008). Recent studies have been beginning to disclose a critical role of Rps6 in a signalling network involved in the regulation of cell size (Meyuhas \& Dreazen 2009). Although many links and effectors are still unknown, central components of this network include the mammalian target of rapamycin and its downstream effectors, the ribosomal protein S6 kinase (S6K) and the translational repressor EIF4e-binding protein (Magnuson et al. 2012). A knockout in mouse carrying mutations at all phosphorylation sites in the primary S6K substrate, Rps6, has provided insights into the physiological role of this protein phosphorylation. In addition to its role in glucose homeostasis in the whole mouse, phosphorylation of Rps6 was shown to be essential for regulating the size of at least some cell types (Ruvinsky \& Meyuhas 2006). Rps6 phosphorylation is a determinant of cell size and glucose homeostasis. Embryo fibroblasts from mice lacking phosphorylated Rsp6 are significantly smaller than controls and display an increased rate of protein synthesis and accelerated cell division (Ruvinsky et al. 2005).

In summary, based on the current data showing a low expression of ribosomal proteins and translation initiation factors such as Egr1, Rpl21 and Eif4a1 in Cx43 ${ }^{\text {del/del }}$ mouse oocytes and Rp/15 and Eif4g2 in the resulting blastocysts, we argue that the mouse oocyte accumulates defects during the growing phase, which significantly compromise its developmental capacity. These implications take into account the differentially expressed genes related to the translational machinery and metabolism. It seems that the blastocysts resulting from such oocytes, which grow within a confined space until implantation, are unable to generate enough biological mass to allow its expansion. Nevertheless, the possibility that $\mathrm{C} \times 43$ depletion in the oocyte might also lead to an inadequate transfer of nutrients from the follicular somatic cells into the oocytes cannot be ruled out. This in turn could affect acquisition of developmental competence and the subsequent impaired embryo development.

\section{Declaration of interest}

The authors declare that there is no conflict of interest that could be perceived as prejudicing the impartiality of the research reported.

\section{Funding}

This study was supported by ISF (grant number 495/08) and the Dwek Fund for Biomedical Research (to N Dekel). N Dekel is the incumbent of the Philip M Klutznick Professorial Chair in Developmental Biology.

\section{Acknowledgements}

The authors thank Itzhak Ino from the Animal Facility for technical assistance; Idan Aharon and Naama Cirkin for genotyping; Dr. Sharon Reikhav for technical help; Dr Ori Brenner for the pathological examination and Ms Martie Spiegel for editorial assistance.

\section{References}

Ackert CL, Gittens JE, O'Brien MJ, Eppig JJ \& Kidder GM 2001 Intercellular communication via connexin43 gap junctions is required for ovarian folliculogenesis in the mouse. Developmental Biology 233 258-270. (doi:10.1006/dbio.2001.0216)

Baird DT, Collins J, Egozcue J, Evers LH, Gianaroli L, Leridon H, Sunde A, Templeton A, Van Steirteghem A, Cohen J et al. 2005 Fertility and ageing. Human Reproduction Update 11 261-276. (doi:10.1093/ humupd/dmi006)

Bettegowda A, Patel OV, Ireland JJ \& Smith GW 2006 Quantitative analysis of messenger RNA abundance for ribosomal protein L-15, cyclophilin-A, phosphoglycerokinase, $\beta$-glucuronidase, glyceraldehyde 3-phosphate dehydrogenase, $\beta$-actin, and histone $\mathrm{H} 2 \mathrm{~A}$ during bovine oocyte maturation and early embryogenesis in vitro. Molecular Reproduction and Development 73 267-278. (doi:10.1002/mrd.20333)

Chaddha V, Viero S, Huppertz B \& Kingdom J 2004 Developmental biology of the placenta and the origins of placental insufficiency. Seminars in Fetal \& Neonatal Medicine 9 357-369. (doi:10.1016/j.siny.2004.03.006)

Choe C, Cho YW, Kim CW, Son DS, Han J \& Kang D 2010 Identification of differentially expressed genes in bovine follicular cystic ovaries. Korean Journal of Physiology \& Pharmacology 14 265-272. (doi:10.4196/kjpp. 2010.14.5.265)

Dekel N, Lawrence TS, Gilula NB \& Beers WH 1981 Modulation of cell-to-cell communication in the cumulus-oocyte complex and the regulation of oocyte maturation by LH. Developmental Biology 86 356-362. (doi:10.1016/0012-1606(81)90193-7)

De Sousa PA, Westhusin ME \& Watson AJ 1998 Analysis of variation in relative mRNA abundance for specific gene transcripts in single bovine oocytes and early embryos. Molecular Reproduction and Development 49 119-130. (doi:10.1002/(SICI)1098-2795(199802)49:2 < 119::AIDMRD3 > 3.0.CO;2-S)

Downs SM 1995 The influence of glucose, cumulus cells, and metabolic coupling on ATP levels and meiotic control in the isolated mouse oocyte. Developmental Biology 167 502-512. (doi:10.1006/dbio.1995.1044)

Dumollard R, Duchen M \& Carroll J 2007 The role of mitochondrial function in the oocyte and embryo. Current Topics in Developmental Biology 77 21-49. (doi:10.1016/S0070-2153(06)77002-8)

Epifano O, Liang LF, Familari M, Moos MC Jr \& Dean J 1995 Coordinate expression of the three zona pellucida genes during mouse oogenesis. Development 121 1947-1956.

Eppig JJ 1996 Coordination of nuclear and cytoplasmic oocyte maturation in eutherian mammals. Reproduction, Fertility, and Development 8 485-489. (doi:10.1071/RD9960485)

Espey LL, Ujioka T, Russell DL, Skelsey M, Vladu B, Robker RL, Okamura H \& Richards JS 2000 Induction of early growth response protein-1 gene expression in the rat ovary in response to an ovulatory dose of human chorionic gonadotropin. Endocrinology 141 2385-2391.

Gardner DK, Lane M \& Schoolcraft WB 2000 Culture and transfer of viable blastocysts: a feasible proposition for human IVF. Human Reproduction 15 (Suppl 6) 9-23.

Gershon E, Plaks V \& Dekel N 2008a Gap junctions in the ovary: expression, localization and function. Molecular and Cellular Endocrinology 282 18-25. (doi:10.1016/j.mce.2007.11.001) 
Gershon E, Plaks V, Aharon I, Galiani D, Reizel Y, Sela-Abramovich S, Granot I, Winterhager E \& Dekel N 2008b Oocyte-directed depletion of connexin43 using the Cre-LoxP system leads to subfertility in female mice. Developmental Biology 313 1-12. (doi:10.1016/j.ydbio.2007.08.041)

Gingras AC, Raught B \& Sonenberg N 1999 elF4 initiation factors: effectors of mRNA recruitment to ribosomes and regulators of translation. Annual Review of Biochemistry 68 913-963. (doi:10.1146/annurev.biochem.68. 1.913)

Gittens JE \& Kidder GM 2005 Differential contributions of connexin37 and connexin 43 to oogenesis revealed in chimeric reaggregated mouse ovaries. Journal of Cell Science 118 5071-5078. (doi:10.1242/jcs.02624)

Huang da W, Sherman BT \& Lempicki RA 2009 Systematic and integrative analysis of large gene lists using DAVID bioinformatics resources. Nature Protocols 4 44-57. (doi:10.1038/nprot.2008.211)

Hutchins AP, Roberts GR, Lloyd CW \& Doonan JH 2004 In vivo interaction between CDKA and elF4A: a possible mechanism linking translation and cell proliferation. FEBS Letters 556 91-94. (doi:10.1016/S00145793(03)01382-6)

Israely T, Dafni H, Granot D, Nevo N, Tsafriri A \& Neeman M 2003 Vascular remodeling and angiogenesis in ectopic ovarian transplants: a crucial role of pericytes and vascular smooth muscle cells in maintenance of ovarian grafts. Biology of Reproduction 68 2055-2064. (doi:10.1095/biolreprod.102.011734)

Juneja SC, Barr KJ, Enders GC \& Kidder GM 1999 Defects in the germ line and gonads of mice lacking connexin43. Biology of Reproduction $\mathbf{6 0}$ 1263-1270. (doi:10.1095/biolreprod60.5.1263)

Kondrashov N, Pusic A, Stumpf CR, Shimizu K, Hsieh AC, Xue S, Ishijima J, Shiroishi T \& Barna M 2011 Ribosome-mediated specificity in Hox mRNA translation and vertebrate tissue patterning. Cell 145 383-397. (doi:10.1016/j.cell.2011.03.028)

Krisher RL 2004 The effect of oocyte quality on development. Journal of Animal Science 82 (E-Suppl) E14-E23. (doi:10.1016/S1937-6448(08) 00801-0)

Lan ZJ, Xu X \& Cooney AJ 2004 Differential oocyte-specific expression of Cre recombinase activity in GDF-9-iCre, Zp3cre, and Msx2Cre transgenic mice. Biology of Reproduction 71 1469-1474. (doi:10.1095/biolreprod. 104.031757)

Lane M \& Gardner DK 2000 Regulation of ionic homeostasis by mammalian embryos. Seminars in Reproductive Medicine 18 195-204. (doi:10.1055/ s-2000-12558)

Lee SL, Sadovsky Y, Swirnoff AH, Polish JA, Goda P, Gavrilina G \& Milbrandt J 1996 Luteinizing hormone deficiency and female infertility in mice lacking the transcription factor NGFI-A (Egr-1). Science $\mathbf{2 7 3}$ 1219-1221. (doi:10.1126/science.273.5279.1219)

Leunda-Casi A, De Hertogh R \& Pampfer S 2001 Decreased expression of fibroblast growth factor-4 and associated dysregulation of trophoblast differentiation in mouse blastocysts exposed to high D-glucose in vitro. Diabetologia 44 1318-1325. (doi:10.1007/s001250100633)

Loreni F, Francesconi A, Jappelli R \& Amaldi F 1992 Analysis of mRNAs under translational control during Xenopus embryogenesis: isolation of new ribosomal protein clones. Nucleic Acids Research 20 1859-1863. (doi:10.1093/nar/20.8.1859)

Magnuson B, Ekim B \& Fingar DC 2012 Regulation and function of ribosomal protein $\mathrm{S} 6$ kinase (S6K) within mTOR signalling networks. Biochemical Journal 441 1-21. (doi:10.1042/BJ20110892)

Meyuhas O 2008 Physiological roles of ribosomal protein S6: one of its kind. International Review of Cell and Molecular Biology 268 1-37. (doi:10.1016/S1937-6448(08)00801-0)

Meyuhas O \& Dreazen A 2009 Ribosomal protein S6 kinase from TOP mRNAs to cell size. Progress in Molecular Biology and Translational Science 90 109-153. (doi:10.1016/S1877-1173(09)90003-5)

Mitchell PA \& Burghardt RC 1986 The ontogeny of nexuses (gap junctions) in the ovary of the fetal mouse. Anatamoical Record 214 283-288. (doi:10.1002/ar.1092140307)

Norris RP, Ratzan WJ, Freudzon M, Mehlmann LM, Krall J, Movsesian MA, Wang H, Ke H, Nikolaev VO \& Jaffe LA 2009 Cyclic GMP from the surrounding somatic cells regulates cyclic AMP and meiosis in the mouse oocyte. Development 136 1869-1878. (doi:10.1242/dev.035238)

Paronetto MP, Bianchi E, Geremia R \& Sette C 2008 Dynamic expression of the RNA-binding protein Sam68 during mouse pre-implantation development. Gene Expression Patterns 8 311-322. (doi:10.1016/j.gep.2008.01.005)
Perez-Armendariz EM, Saez JC, Bravo-Moreno JF, Lopez-Olmos V, Enders GC \& Villalpando I 2003 Connexin43 is expressed in mouse fetal ovary. Anatomical Record. Part A, Discoveries in Molecular, Cellular, and Evolutionary Biology 271 360-367. (doi:10.1002/ar.a.10040)

Plaks V, Kalchenko V, Dekel N \& Neeman M 2006 MRI analysis of angiogenesis during mouse embryo implantation. Magnetic Resonance in Medical Sciences 5 1013-1022. (doi:10.1002/mrm.20881)

Reaume AG, de Sousa PA, Kulkarni S, Langille BL, Zhu D, Davies TC, Juneja SC, Kidder GM \& Rossant J 1995 Cardiac malformation in neonatal mice lacking connexin43. Science 267 1831-1834. (doi:10.1126/science.7892609)

Robert C, Gagne D, Bousquet D, Barnes FL \& Sirard MA 2001 Differential display and suppressive subtractive hybridization used to identify granulosa cell messenger rna associated with bovine oocyte developmental competence. Biology of Reproduction 64 1812-1820. (doi:10.1095/biolreprod64.6.1812)

Ruvinsky I \& Meyuhas O 2006 Ribosomal protein S6 phosphorylation: from protein synthesis to cell size. Trends in Biochemical Science 31 342-348. (doi:10.1016/j.tibs.2006.04.003)

Ruvinsky I, Sharon N, Lerer T, Cohen H, Stolovich-Rain M, Nir T, Dor Y, Zisman P \& Meyuhas O 2005 Ribosomal protein S6 phosphorylation is a determinant of cell size and glucose homeostasis. Genes and Development 19 2199-2211. (doi:10.1101/gad.351605)

Simon AM, Goodenough DA, Li E \& Paul DL 1997 Female infertility in mice lacking connexin 37. Nature 385 525-529. (doi:10.1038/385525a0)

Sosinsky GE \& Nicholson BJ 2005 Structural organization of gap junction channels. Biochimica et Biophysica Acta 1711 99-125. (doi:10.1016/ j.bbamem.2005.04.001)

Theis M, de Wit C, Schlaeger TM, Eckardt D, Kruger O, Doring B, Risau W, Deutsch U, Pohl U \& Willecke K 2001 Endothelium-specific replacement of the connexin 43 coding region by a lacZ reporter gene. Genesis 29 1-13. (doi:10.1002/1526-968X(200101)29:1 < 1::AID-GENE1000> 3.0.CO;2-0)

Trounson A, Anderiesz C \& Jones G 2001 Maturation of human oocytes in vitro and their developmental competence. Reproduction 121 51-75. (doi:10.1530/rep.0.1210051)

Unger VM, Kumar NM, Gilula NB \& Yeager M 1999 Three-dimensional structure of a recombinant gap junction membrane channel. Science $\mathbf{2 8 3}$ 1176-1180. (doi:10.1126/science.283.5405.1176)

Vaccari S, Weeks JL II, Hsieh M, Menniti FS \& Conti M 2009 Cyclic GMP signaling is involved in the luteinizing hormone-dependent meiotic maturation of mouse oocytes. Biology of Reproduction 81 595-604. (doi:10.1095/biolreprod.109.077768)

de Vries WN, Binns LT, Fancher KS, Dean J, Moore R, Kemler R \& Knowles BB 2000 Expression of Cre recombinase in mouse oocytes: a means to study maternal effect genes. Genesis 26 110-112. (doi:10. 1002/(SICI)1526-968X(200002)26:2 < 110::AID-GENE2 > 3.0.CO;2-8)

Wang HX, Tong D, El-Gehani F, Tekpetey FR \& Kidder GM 2009 Connexin expression and gap junctional coupling in human cumulus cells: contribution to embryo quality. Journal of Cellular and Molecular Medicine 13 972-984. (doi:10.1111/j.1582-4934.2008.00373.x)

Winterhager E, Grummer R, Jahn E, Willecke K \& Traub O 1993 Spatial and temporal expression of connexin26 and connexin 43 in rat endometrium during trophoblast invasion. Developmental Biology 157 399-409. (doi:10.1006/dbio.1993.1144)

Yoshino M, Mizutani T, Yamada K, Tsuchiya M, Minegishi T, Yazawa T, Kawata H, Sekiguchi T, Kajitani T \& Miyamoto K 2002 Early growth response gene- 1 regulates the expression of the rat luteinizing hormone receptor gene. Biology of Reproduction 66 1813-1819. (doi:10.1095/ biolreprod66.6.1813)

Zeisel A, Amir A, Kostler WJ \& Domany E 2010 Intensity dependent estimation of noise in microarrays improves detection of differentially expressed genes. BMC Bioinformatics 11 400. (doi:10.1186/1471-210511-400)

Received 20 August 2013

First decision 4 September 2013

Revised manuscript received 24 March 2014

Accepted 3 April 2014 